\title{
New Delhi metallo- $\beta$-lactamase- 1 among Escherichia coli strains isolated from leukemia patients in Iran: two case reports
}

\author{
Mahdane Roshani ${ }^{1}$, Alireza Goodarzi ${ }^{2}$, Sanaz Dehbashi ${ }^{1}$, Farhad Afrasiabi ${ }^{1}$, Hossein Goudarzi ${ }^{3}$, Ali Hashemi ${ }^{3}$ and \\ Mohammad Reza Arabestani ${ }^{1 *}$ (D)
}

\begin{abstract}
Background: Escherichia coli has appeared as an important opportunistic pathogen responsible for nosocomial infections in patients with immunodeficiency, particularly in leukemia patients. New Delhi metallo-beta-lactamase is an enzyme originally found in Enterobacteriaceae.

Case presentation: In this study, 80 isolates of Escherichia coli and Klebsiella pneumoniae were collected over the course of 2 years from two medical centers in Tehran, Iran. Production of carbapenemase was detected in the isolates using modified Hodge test. New Delhi metallo-beta-lactamase-1 genes were detected by polymerase chain reaction amplification with specific primers. Two New Delhi metallo-beta-lactamase-1-producing Escherichia coli strains were isolated from two Iranian patients with leukemia. These two patients were 6 and 15 years old, one female and the other male, from two oncology centers in Iran. The isolates were resistant to carbapenems (imipenem, meropenem), and two isolates were positive for carbapenemase production by modified Hodge test.

Conclusions: The emergence of New Delhi metallo-beta-lactamase-1-producing Escherichia coli is a threat for leukemia patients in oncology and hematology departments. We conclude that the incidence of multidrug resistant pathogens has increased among patients with leukemia and is life threatening.
\end{abstract}

Keywords: bla $a_{\mathrm{NDM}-1}$, Escherichia coli, Klebsiella pneumoniae, Leukemia

\section{Introduction}

The globally increasing prevalence of New Delhi metalloß-lactamase-1 (NDM-1)-producing Enterobacteriaceae is a concerning phenomenon in immunocompromised patients. Previous results indicated that $b l a_{\mathrm{NDM}-1}$ gene can be carried on incompatibility group $\mathrm{N}(\mathrm{IncN})$ plasmids of different sizes along with other resistance factors. bla $a_{\mathrm{NDM}-1}$ can confer resistance to almost all the $\beta$-lactams. Thus, bacteria carrying NDM-1 gene are

\footnotetext{
*Correspondence: mohammad.arabestani@gmail.com

${ }^{1}$ Department of Microbiology, Faculty of Medicine, Nutrition Research

Center, Hamadan University of Medical Sciences, Shahid Fahmideh Street, Park Mardome, Hamadan, IR, Iran

Full list of author information is available at the end of the article
}

considered to be resistant to all antibiotic classes except colistin and ciprofloxacin. The gene was scarcely integrated into the chromosome. The sequencing of this gene suggests a new enzyme, unrelated to hitherto known metallo $\beta$-lactamases (MBLs). The most similar known type is Verona integron-encoded metallo- $\beta$-lactamase (VIM-1/VIM-2), sharing 32.4\% resemblance [1]. Immunosuppressive, sepsis, and radiation therapy can be the differential diagnosis of exotic infection [2-5].

In a study conducted in China, the presence of this gene was first reported in a patient with leukemia, but it has mainly been reported in patients with neutropenia. Our study is the first report from Iran. The purpose of this study was to investigate the existence of NDM-1 gene as a original author(s) and the source, provide a link to the Creative Commons licence, and indicate if changes were made. The images or other third party material in this article are included in the article's Creative Commons licence, unless indicated otherwise in a credit line to the material. If material is not included in the article's Creative Commons licence and your intended use is not permitted by statutory regulation or exceeds the permitted use, you will need to obtain permission directly from the copyright holder. To view a copy of this licence, visit http://creativecommons.org/licenses/by/4.0/. The Creative Commons Public Domain Dedication waiver (http://creativeco mmons.org/publicdomain/zero/1.0/) applies to the data made available in this article, unless otherwise stated in a credit line to the data. 
risk factor for life-threatening infection in patients with leukemia.

\section{Case presentation}

In this study, 80 isolates of Escherichia coli and Klebsiella pneumoniae were collected from two medical centers in Tehran, Iran: the Hematology-Oncology Research Center, Dr. Shariati Hospital, and the Mahak Pediatric Oncology Center, between 2014 and 2015.

The bacteria were isolated and stored in Hamadan University of Medical Sciences. All the clinical specimens were quickly sent to the laboratory and analyzed for confirmatory test. Isolates were identified using standard microbiological and biochemical procedures [6]. In our previous study, antibiotic susceptibility of the isolates was tested by Kirby-Bauer disk diffusion method for imipenem, ceftazidime, ceftriaxone, cefotaxime, ciprofloxacin, levofloxacin, amikacin, ampicillin, and gentamicin (all from Mast, UK). Moreover, the combination disk method was employed to detect extended-spectrum $\beta$-lactamase (ESBL)-producing isolates, while the minimum inhibitory concentrations (MICs) of selected antimicrobials were determined by the broth microdilution method. The results were interpreted according to the Clinical Laboratory Standards Institute (CLSI) guidelines [7]. The carbapenem-resistant strains were investigated for carbapenemase production by modified Hodge test (MHT) according to the CLSI guidelines, in which E. coli ATCC25922 was used as the positive control [8]. Furthermore, the combined disk diffusion method was applied for $b l a_{\mathrm{MBL}}$ detection using two IPM $(10 \mu \mathrm{g})$ disks and ethylenediaminetetraacetic acid (EDTA) $0.5 \mathrm{M}$ solution[9]. For diagnosis of the NDM1, polymerase chain reaction (PCR) was performed on DNA extracted by boiling, using NDM-F-specific primers: CAACTGGATCAA GCAGGAGA, NDM-R TCGATCCCAACGGTGATATT (Bioneer Company, Korea) [10].

The sequencing of amplicons in both directions was carried out by the Bioneer Company (Daejeon, South Korea). The data were analyzed using FinchTV software (Geospiza, USA), and the sequences were then confirmed using the National Center for Biotechnology Information (NCBI) website (http://www.ncbi.nlm.nih.gov/ BLAST). A total of 56 E. coli and 24 K. pneumoniae isolates were obtained from urine, blood, sputum, wound, and vagina. Among the 80 isolates, 52 (63\%) strains were ESBL producers, followed by $5(6.25 \%)$ metallo $\beta$-lactamase (MBL) producers. According to our antimicrobial susceptibility test on E. coli and K. pneumoniae isolates, eight (10\%) of $E$. coli isolates were imipenem-resistant. Out of 80 isolates, $8(10 \%)$ isolates were found to be carbapenemresistant. The major MBL and carbapenem-resistant species were $E$. coli. The first NDM-1-containing isolate was obtained from a 26-year-old subject diagnosed with acute leukemia. The second was obtained from a 2-year-old child with acute leukemia. These two NDM-1-positive E. coli isolates (labeled as E1-E2) were recovered from the urine and blood samples of two different hospitalized patients. Both isolates were positive for the modified Hodge test and MBL producers (Tables 1 and 2).

\section{Discussion}

The present study reports NDM-1-producing E. coli strain from the bloodstream and infected urinary tract of two patients. PCR results confirmed that the NDM1-producing E. coli harbored qnrA, qnrB, qnrS and

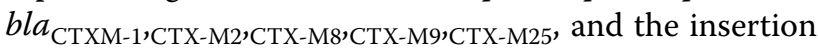
sequence of ISECP1,IS26,IS903. The two NDM-1-producing $E$. coli isolates did not contain $q u r S$ genes, but they carried $b l a_{\text {TEM }}$ gene.

Eyvazi et al. recently reported $b l a_{\mathrm{NDM}-1}$-producing E. coli in Iran for the first time [11]. Shahcheraghi et al. detected the first $b l a_{\mathrm{NDM}-1}$-producing $K$. pneumonia in Iran as well [12].

In October 2011, Laurent Poirel et al. reported $b a_{\mathrm{NDM}}$ ${ }_{1}$-producing $K$. pneumoniae and E. coli. in a 16-year-old male patient admitted to the hematology unit of a hospital in Istanbul, Turkey [13].

In a study in 2010 on a patient transferred from Iraq to France, NDM-1-producing K. pneumoniae was also reported [14].

Reports have also declared the existence of $b a_{\mathrm{NDM}}$ ${ }_{1}$-producing Enterobacteriaceae in Pakistan and Afghanistan $[15,16]$. The $b l a_{\mathrm{NDM}-1}$-producing bacteria could also be found in environmental samples and drinking water [17]. In our investigation, PCR confirmed that the NDM1-producing $E$. coli harbored quinolone resistance gene $\mathrm{B}$ $(q n r B)$ and $b l a_{\text {Стхм-9. This result was similar to the other }}$ reports on strains carrying $b l a_{\mathrm{NDM}-1}$ that also harbored other $\beta$-lactamase genes [18].

An NDM-1-producing E. coli strain was detected in the bloodstream of a patient in this study that exhibited high resistance to all tested $\beta$-lactam antibiotics, which can be attributed to the production of $b l a_{\mathrm{NDM}-1}$ and other resistant genes.

Table 1 Antimicrobial resistance profile of two NDM-1producing $E$. coli isolates from two patients with leukemia

\begin{tabular}{|c|c|c|c|}
\hline \multicolumn{2}{|c|}{ Phenotypic tests for carbapenemase } & \multicolumn{2}{|c|}{$\begin{array}{l}\text { Minimum inhibitory } \\
\text { concentration }(\mu \mathrm{g} / \mathrm{mL}) \\
\text { for antibiotics }\end{array}$} \\
\hline Strains & MHT & IMP & MEM \\
\hline E1 & + & 4 & 8 \\
\hline E2 & + & 16 & 32 \\
\hline
\end{tabular}


Table 2 Distribution of cefotaxime-resistant (CTX-M) group, gnr genes, TEM gene, IS903, IS26, and ISEcp1 elements in NDM-1producing E. coli isolated from leukemia patients

\begin{tabular}{lllllllllllll}
\hline & CTXM1 & CTXM2 & CTXM8 & CTXM9 & CTXM25 & ISECP1 & IS26 & IS903 & qnrA & qnrB & qnrS & TEM \\
\hline $\mathrm{E} 1$ & + & - & - & + & - & + & + & + & & + & + & - \\
$\mathrm{E} 2$ & + & - & - & - & - & + & + & - & - & - & - & + \\
\hline
\end{tabular}

Bahramian et al. published the first report about metallo- $\beta$-lactamase-6 (NDM-6) among K. pneumoniae in New Delhi. ST147 strains were also isolated from dialysis patients in Iran [19]. Firoozeh et al. reported 20 (11.1\%) K. pneumoniae isolates harboring bla $a_{\mathrm{NDM}-1}$ gene (20).

We inferred that it is important to evaluate the health condition of immunocompromised patients, especially those with leukemia. Moreover, patients receiving chemotherapy may develop bloodstream infections. Bacterial infections can result in significant morbidity and mortality due to the development of febrile neutropenia and bacteremia.

\section{Conclusion}

This is the first report on the $b l a_{\mathrm{NDM}-1}$-producing E. coli strains isolated from leukemia patients in Iran. NDM1-producing $E$. coli also harbored genes encoding cefotaxime-resistant (CTX-M) group, TEM, quinolone resistance (QNR), and insertion sequence of resistance enzymes. The coincidence of $N D M-1$ with other antibiotic-resistance genes may further limit the treatment options and makes infection control procedures more challenging among leukemia patients. Our results show the emergence of $b l a_{\mathrm{NDM}-1}$ as an alarm to our health services, particularly among immunocompromised patients.

\section{Abbreviations}

NDM-1: New Delhi metallo- $\beta$-lactamase-1; ESBL: Extended spectrum $\beta$-lactamase; MIC: Minimum inhibitory concentration; MBL: Metallo- $\beta$ lactamase; VIM: Verona integron-encoded metallo- $\beta$-lactamase; Qnr: Quinolone resistance; bla: Beta lactamase.

\section{Acknowledgements}

The authors of this article are grateful to Hamadan University of Medical Sciences for their financial support in conducting the research.

\section{Authors' contributions}

MR, FA, and SD performed microbiological and molecular tests and wrote the manuscript. $A G, A H$, and $H G$ played a role in project administration. MRA supervised all of the stages of designing the study, conducting the research, and writing the manuscript. All authors read and approved the final manuscript.

\section{Funding}

This article was conducted on financial support of vice-chancellor for research of Hamadan University of Medical Sciences (project number 980203554).

\section{Availability of data and materials}

The datasets used and/or analyzed during the current study are available from the corresponding author on reasonable request.

\section{Declarations}

\section{Ethics approval and consent to participate}

This study was approved by the Ethics Committee of Hamadan University of Medical Sciences (code no. IR.UMSHA.REC.1398.004).

\section{Consent for publication}

Written informed consent was obtained from the patients" legal guardian for publication of this case report and any accompanying images. A copy of the written consent is available for review by the Editor-in-Chief of this journal.

\section{Competing interests}

The authors declare that they have no competing interests

\section{Author details}

${ }^{1}$ Department of Microbiology, Faculty of Medicine, Nutrition Research Center, Hamadan University of Medical Sciences, Shahid Fahmideh Street, Park Mardome, Hamadan, IR, Iran. ${ }^{2}$ Department of Medical Laboratory Sciences, School of Paramedicine, Hamadan University of Medical Sciences, Shahid Fahmideh Street, Park Mardome, Hamadan, IR, Iran. ${ }^{3}$ Department of Microbiology, Shahid Beheshti University of Medical Sciences, Shahid Shahriari Square, Daneshjou Boulevard, Shahid Chamran Highway, 1983969411 Tehran, Iran.

Received: 10 August 2021 Accepted: 19 October 2021

Published online: 25 November 2021

\section{References}

1. Yong D, Toleman MA, Giske CG, Cho HS, Sundman K, Lee K, et al. Characterization of a new metallo- $\beta$-lactamase gene, blaNDM-1, and a novel erythromycin esterase gene carried on a unique genetic structure in Klebsiella pneumoniae sequence type 14 from India. Antimicrob Agents Chemother. 2009;53(12):5046-54.

2. Devaraj NK. Antibiotic resistance: a real menace. Oman Med J. 2017;32(6):531

3. Devaraj NK, Aneesa A, Abdul Hadi A, Shaira N. Topical corticosteroids in clinical practice. Med J Malaysia. 2019;74(2):187-9.

4. Devaraj NK. A recurrent cutaneous eruption. BMJ Case Rep. 2019. https:// doi.org/10.1136/bcr-2018-228355.

5. Devaraj NK, Suppiah S, Veettil SK, Ching SM, Lee KW, Menon RK, et al. The effects of probiotic supplementation on the incidence of diarrhea in cancer patients receiving radiation therapy: a systematic review with meta-analysis and trial sequential analysis of randomized controlled trials. Nutrients. 2019;11(12):2886.

6. Forbes BA, Sahm DF, Weissfeld AS, Bailey WR. Bailey \& Scott's diagnostic microbiology. St. Louis, Mo: Elsevier Mosby; 2007.

7. Patel JB, Cockerill F, Bradford PA. Performance standards for antimicrobial susceptibility testing: twenty-fifth informational supplement. 2015; 35(1).

8. Lee K, Chong Y, Shin H, Kim Y, Yong D, Yum J. Modified Hodge and EDTA-disk synergy tests to screen metallo- $\beta$-lactamase-producing strains of Pseudomonas and Acinetobacter species. Clin Microbiol Infect. 2001;7(2):88-91.

9. Yong D, Lee K, Yum JH, Shin HB, Rossolini GM, Chong Y. Imipenem-EDTA disk method for differentiation of metallo- $\beta$-lactamase-producing clinical 
isolates of Pseudomonas spp. and Acinetobacter spp. J Clin Microbiol. 2002:40(10):3798-801.

10. Teo J, Ngan G, Balm M, Jureen R, Krishnan P, Lin R. Molecular characterization of NDM-1 producing Enterobacteriaceae isolates in Singapore hospitals. WPSAR. 2012;3(1):19.

11 Eyvazi S, Hakemi-Vala M, Hashemi A, BagheriBejestani F, Elahi N. Emergence of NDM-1-producing Escherichia coli in Iran. Arch Clin Infect Dis. 2017. https://doi.org/10.5812/archcid.62029.

12. Shahcheraghi F, Nobari S, Rahmati Ghezelgeh F, Nasiri S, Owlia P, Nikbin VS, et al. First report of New Delhi metallo-beta-lactamase-1-producing Klebsiella pneumoniae in Iran. Microb Drug Resist. 2013;19(1):30-6.

13. Poirel L, Özdamar M, Ocampo-Sosa AA, Türkoglu S, Ozer UG, Nordmann P. NDM-1-producing Klebsiella pneumoniae now in Turkey. Antimicrob Agents Chemother. 2012;56(5):2784-5.

14. Poirel L, Fortineau N, Nordmann P. International transfer of NDM-1-producing Klebsiella pneumoniae from Iraq to France. Antimicrob Agents Chemother. 2011;55(4):1821-2.

15. Kumarasamy KK, Toleman MA, Walsh TR, Bagaria J, Butt F, Balakrishnan $R$, et al. Emergence of a new antibiotic resistance mechanism in India, Pakistan, and the UK: a molecular, biological, and epidemiological study. Lancet Infect Dis. 2010;10(9):597-602.

16. Mc Gann P, Hang J, Clifford RJ, Yang Y, Kwak YI, Kuschner RA, et al. Complete sequence of a novel 178-kilobase plasmid carrying blaNDM-1 in a Providencia stuartii strain isolated in Afghanistan. Antimicrob Agents Chemother. 2012;56(4):1673-9.

17. Walsh TR, Weeks J, Livermore DM, Toleman MA. Dissemination of NDM-1 positive bacteria in the New Delhi environment and its implications for human health: an environmental point prevalence study. Lancet Infect Dis. 2011;11(5):355-62.

18. Zhang X, Du J, Zhou C, Cao J, Lu H, Liu H, et al. An uncommon ST1224 NDM-1-producing Klebsiella pneumoniae isolated from the bloodstream of a leukemia patient in China. Chemotherapy. 2017:62(4):262-8.

19. Bahramian A, Shariati A, Azimi T, Sharahi JY, Bostanghadiri N, Gachkar L, et al. First report of New Delhi metallo- $\beta$-lactamase-6 (NDM-6) among Klebsiella pneumoniae ST147 strains isolated from dialysis patients in Iran. Infect Genet Evol. 2019;69:142-5.

20. Firoozeh F, Mahluji Z, Shams E, Khorshidi A, Zibaei M. New Delhi metallo$\beta$-lactamase-1-producing Klebsiella pneumoniae isolates in hospitalized patients in Kashan Iran. Iran J Microbiol. 2017;9(5):283.

\section{Publisher's Note}

Springer Nature remains neutral with regard to jurisdictional claims in published maps and institutional affiliations.
Ready to submit your research? Choose BMC and benefit from:

- fast, convenient online submission

- thorough peer review by experienced researchers in your field

- rapid publication on acceptance

- support for research data, including large and complex data types

- gold Open Access which fosters wider collaboration and increased citations

- maximum visibility for your research: over $100 \mathrm{M}$ website views per year

At BMC, research is always in progress.

Learn more biomedcentral.com/submissions 